\title{
ISOLATION OF MAGNETOTACTIC BACTERIA FROM ENVIRONMENTAL SAMPLES AND OPTIMIZATION AND CHARACTERIZATION OF EXTRACTED MAGNETOSOMES
}

\author{
SALAM, M. A. ${ }^{1}-$ KHAN, A. ${ }^{1}-$ RAFIQ, M. $^{2}-$ SHAH, A. A. ${ }^{1}-$ HASAN, F. ${ }^{1 *}$ \\ ${ }^{1}$ Department of Microbiology, Quaid-i-Azam University, Islamabad 44000, Pakistan \\ ${ }^{2}$ Bristol Glaciology Centre, School of Geographical Sciences, University of Bristol \\ Bristol BS8 1SS, United Kingdom \\ *Corresponding author \\ e-mail: farihahasan@yahoo.com; phone: +92-51-9064-3065
}

(Received $17^{\text {th }}$ Oct 2018; accepted $2^{\text {nd }}$ Jan 2019)

\begin{abstract}
Magnetotactic bacteria (MTB) have ability to accumulate biominerals intracellularly as iron nanoparticles in the form of ferric oxide (Magnetite) and ferric sulphide (Greigite), known as magnetosomes. Most of them belong to the $\alpha$-proteobacteria, $\beta$-proteobacteria and $\gamma$-proteobacteria class. In Pakistan, the magnetotactic bacterial strains are not yet isolated. In current study, the Magnetotactic bacterial strains are isolated from different environmental samples and a modified specific growth medium was used to culture the isolated MTB strains. The technique used for accumulation of bacteria in water samples was the magnetic enrichment technique. The isolation of magnetotactic bacteria is difficult and identified number of strains of magnetotactic bacteria is less than a hundred. So, there is a need to focus more on the identification and classification of MTB. The selected strains were cultured on scale up production and extraction of magnetosomes were carried out by Boiling method. The extracted magnetosomes were characterized by Scanning electron microscopy (SEM), Fourier Transform Infrared (FTIR) spectroscopy and X-ray powder diffraction (XRD).
\end{abstract}

Keywords: magnetosomes, scanning electron microscopy, X-ray powder diffraction, Fourier transform infrared spectroscopy

\section{Introduction}

Many organisms can sense the geomagnetic field and this behaviour of organisms is known as "magneto-reception" (Kirschvink et al., 2001). The well-understood example of magneto-reception is present in prokaryotic organisms that can sense and align themselves along with the geomagnetic field lines (Lefévre et al., 2011b). Those prokaryotes are known as Magnetotactic bacteria (MTB). The evolutionary history of magnetotaxis of MTB might be complex as magnetotaxis in the domain Bacteria is an ancient physiological trait (Lin et al., 2018). Magnetotactic bacteria are a diverse and fascinating group of micro-organisms that shared the ability of orientation towards the geomagnetic fields. The presence of iron oxide and sulphide molecules in bacterial cell makes them little compasses that have ability to direct themselves to the magnetic field lines (Bazylinski and Frankel, 2004). This attribute of MTB is due to the intracellular biomineralization of iron nanoparticles of ferric oxide (magnetite) and ferric sulfide (greigite), known as magnetosomes, which are responsible for magnetotaxis in MTB (Lefèvre and Bazylinski, 2013; Bazylinski et al., 2000). Magnetosomes are individually enclosed by a thin organic covering that confers high and constant dispersion in aqueous solutions as compared with artificial magnetite and this attribute make them ideal for use in biotechnological purpose (Arakaki et al., 2008). These magnetosomes are enclosed within a bilayer membrane that is thought to be an invagination of cytoplasmic 
membrane, known as magnetosome membrane. The bacterial cells use the iron that accumulated in cell by the process of biomineralization. Different types of mechanism are used for assimilation and utilization of iron present in the cell (Tanaka et al., 2010). According to $\mathrm{Li}$ et al. (2017), extreme environment could provide the knowledge regarding to the evolution of magnetotaxis and biomineralization in MTB. Although magnetotactic bacteria (MTB) are present in various aquatic environments but the majorities of them are still uncultivable (Flies et al., 2005).

MTB are heterogeneous group of microorganisms, which are numerous in aquatic habitats. MTB are commonly resided in Oxic-Anoxic Interface (OAI) of chemically stratified zone where oxygen is present in low concentrations (Simmons et al., 2004). Magnetite-producing MTB are present in fresh water as well as marine water, while greigite-producing reside marine sediments (Bazylinski and Frankel, 2004). All identified MTB are gram negative as well as positive and microaerophilic in nature. The detection of MTB is easy as they move towards the magnetic field but the cultivation process id difficult (Shivangi and Sinha, 2017). According to Loghin et al. (2017), the magnetic gradient can be used to detect the MTB and can control their movements. MTB include various morphological forms as cocci, bacilli, vibrio, ovoids, spirilla and multicellular aggregates (Schuler et al., 1999).

The current study is about the isolation of magnetotactic bacteria from Pakistan fresh water samples. The magnetotactic bacteria were then optimized and were grew in broth medium. The magnetosomes were extracted and characterized by using analytical techniques, i.e. Scanning Electron Microscopy (SEM), Fourier-transform infrared spectroscopy (FTIR) and X-ray powder diffraction (XRD).

\section{Material and methodology}

\section{Collection of water sample and magnetic enrichment technique}

The water samples were collected from Tatta Pani $\left(31.2488^{\circ} \mathrm{N}, 77.0895^{\circ} \mathrm{E}\right.$, Kashmir) and Attabad Lake (36.19 $9^{\circ} \mathrm{N}, 4.48^{\circ} \mathrm{E}$, Hunza) in May, 2017 from Pakistan (Fig. 1). The collection of water samples were done in Nalgene sample bottles with magnet inside the bottle. The collection was done about 2-3 feet below the water surface where the oxygen concentration was low and settled down the bottle for $30 \mathrm{~min}$. Then the bottle was carefully closed tightly. The magnetic enrichment technique was used to accumulate the magnetotactic bacteria in water samples by placing bar magnets to the outer wall of sampling jars at room temperature. After 15 days water sample was collected from immediate vicinity of attached magnet so that the chance of isolation of magnetotactic bacteria might be increased (Flies et al., 2005b; Jogler et al., 2010).

\section{Medium composition}

The specific growth culturing medium was used for the magnetotactic bacterial growth, named. The composition of the medium was 5 g.L. ${ }^{-1}$ of tryptone, 3 g.L - $^{-1}$ of beef extract, $5 \mathrm{~g} . \mathrm{L}^{-1}$ of sodium chloride, $20 \mathrm{ml} . \mathrm{L}^{-1}$ of ferric quinate solution (Sharma and Chandrajit, 2011).

\section{Isolation and detection of magnetotactic bacteria}

About $0.5 \mathrm{ml}$ of magnetically enriched water sample was spread on specific growth medium. The colonies were then detected on glass slides by movement of magnetotactic 
bacteria as the magnet was placed near the glass slide under compound microscope. The movement of the culture was observed, and the obtained cultures were further confirmed by hanging drop method. Sulphate Indole Medium was used to check the motility of the bacterial strains (Waghmare et al., 2018).

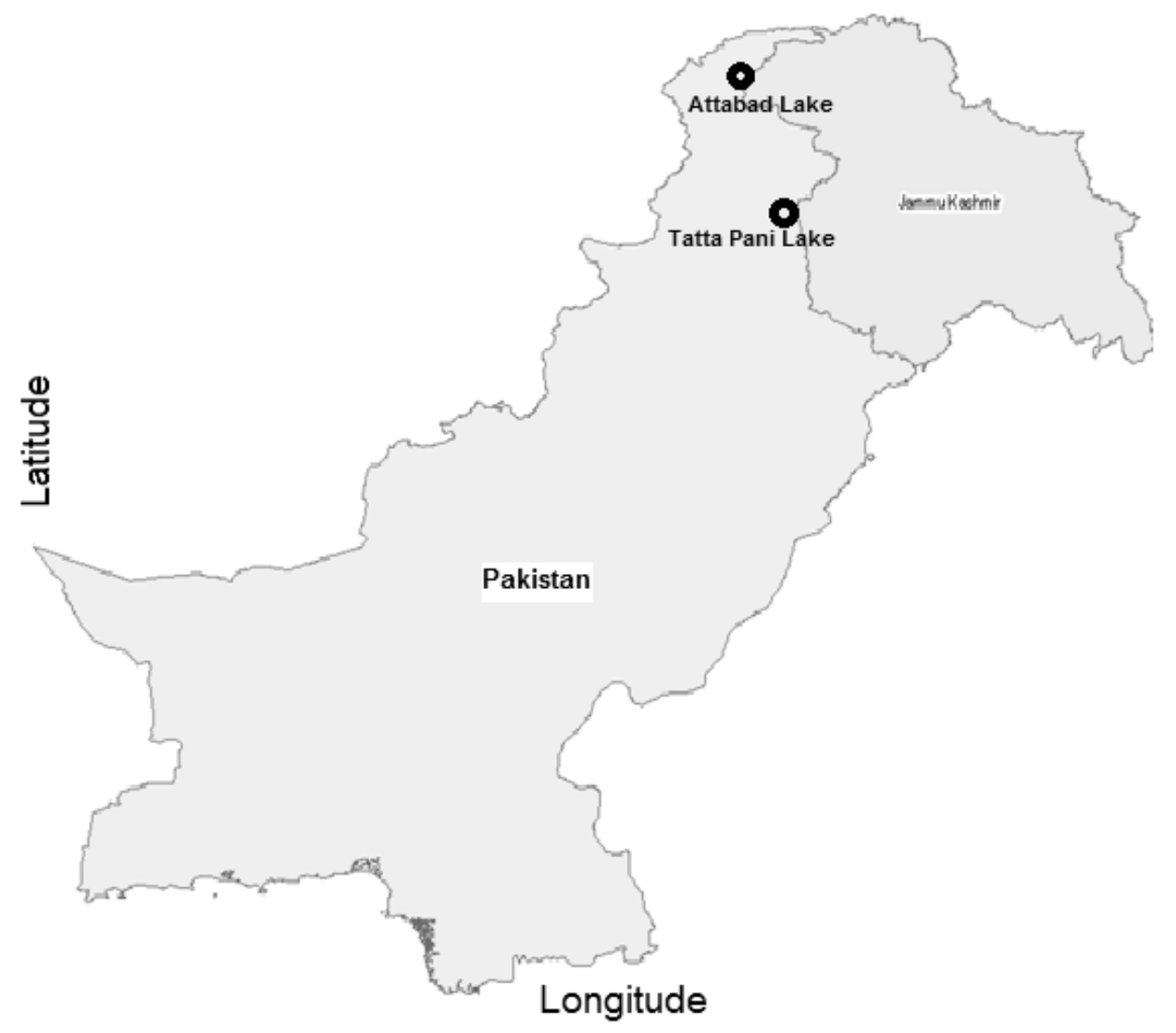

Figure 1. A map indicating the location of sampling sites: Attabad Lake and Tatta Pani

\section{Molecular identification through 16S rRNA gene sequencing}

The total genomic DNA of selected bacterial strains was extracted by using Phenol/chloroform DNA extraction protocol. DNA was partially sequenced for $16 \mathrm{~S}$ rRNA gene by Macrogen, Inc., Seoul, South Korea. Sequences were further analysed for the similar strains in NCBI using BLAST software (http://blast.ncbi.nlm.nih.gov/Blast.cgi/). Phylogenetic trees were constructed by using MEGA 6 software, which determined the relationship of our isolates with the closely related strains.

\section{Optimization of physiological properties of magnetotactic bacteria}

The isolated strains were optimized on different temperatures $\left(17,27,37^{\circ} \mathrm{C}\right)$ and $\mathrm{pH}$ $(6,7,8)$.

\section{Extraction of magnetotactic bacteria}

About $500 \mathrm{ml}$ of specific growth medium was inoculated with the isolated bacterial strains and placed the flask in shaking incubator at $27{ }^{\circ} \mathrm{C}$ for $15-20$ days. The colour of 
the medium changes from light brown to dark brown that indicate the production of iron in the medium.

Boiling technique was used for the extraction of magnetosomes from magnetotactic bacteria. The growth medium was centrifuged at $8000 \mathrm{rpm}$ for $15 \mathrm{~min}$ at $4{ }^{\circ} \mathrm{C}$. The pallet was shifted to test tubes and washed with distilled water two times and then suspended in $5 \mathrm{~N} \mathrm{NaOH}$ solution for $20 \mathrm{~min}$. Then the suspension was boiled by placing the test tubes in water bath for $2 \mathrm{~h}$ or until the suspension was turned into dark brown in colour. Then cool down the suspension and again centrifuge the suspension and collected the pallet in Eppendorf tubes (Frankel RB et al., 1983).

\section{Characterization of magnetosomes}

Different techniques will be used for the physico-chemical characterization of purified magnetosomes.

\section{Scanning electron microscopy (SEM)}

The surface topology of extracted magnetosomes was examined by scanning electron microscopy (JSM5910, JEOL, Japan) to find structure of magnetosomes after extraction. Magnetosomes were thoroughly washed with sterilized distilled water and mounted on copper stubs with gold paint. Gold plating was done in vacuum to increase the conductivity of the samples.

\section{Fourier-transform infrared spectroscopy (FTIR)}

In this study, the ATR-FTIR (Parkin Elmer spectrum 65 FTIR) spectrometer is used for the structural analysis of extracted magnetosomes. The sample was placed on the sample holder. The spectrum was recorded using an attenuated reflectance technique involving diamond crystal. The samples were then scanned from $4000-400 \mathrm{~cm}^{-1}$ with resolution of $6.0 \mathrm{~cm}^{-1}$ and were averaged over 200 scans.

\section{$X$-ray powder diffraction $(X R D)$}

X-ray powder diffraction (Xpert Pro. PANalytical) used for phase identification of a crystalline material and provide information on unit cell dimensions. The phase and purity of extracted magnetosomes were examined by X-ray diffraction (XRD) with $2 \Theta$ range of $5^{\circ}-65^{\circ}$.

\section{Statistical analysis}

Optimization of temperature and $\mathrm{pH}$ were performed in duplicate. All the data with repeated measurements were statistically analysed with T-test.

\section{Results}

The water samples from Tatta Pani lake and Attabad lake were magnetically enriched by placing magnet and two isolates were selected after doing serial dilutions, Gram staining, inoculation in Sulphate Indole Medium to check the motility assessment and conversion of broth colour from light brown to dark brown by broth activity of inoculum. The colour change in broth showed the production of iron in the broth. 


\section{Molecular identification through 16S rRNA gene sequencing}

The 16S rRNA sequences of strains were obtained by Macrogen, Inc., Seoul, Korea. The gene sequences were compared with other sequences in the GenBank databases, using the NCBI BLAST software. The bacterial strains CT-K1 and TP6-4 showed 87\% and $100 \%$ resemblance with Iron sulfide magnetotactic bacteria and Bacillus cereus species of magnetotactic bacteria respectively (Fig. 2). The aligned sequences were then used to construct a phylogenetic tree by neighbour joining method using MEGA6 software. The accession numbers obtained of these strains are MK053797 for CT-K1 and MK053798 for TP6-4.

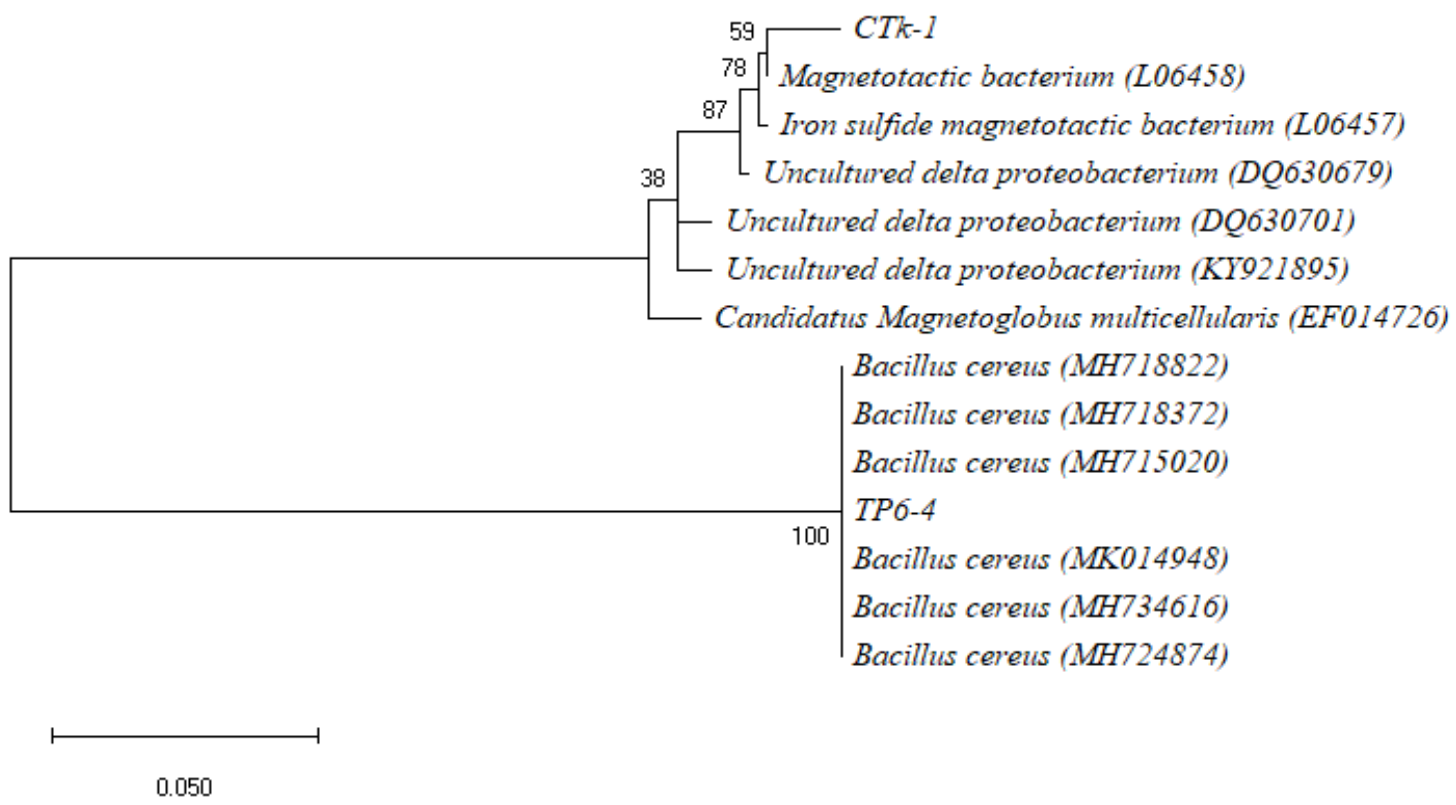

Figure 2. Phylogenetic trees of magnetotactic bacterial strains CT-K1 and TP6-4

\section{Effect of temperature and $\mathrm{pH}$ on growth of magnetotactic bacteria}

Optimization of physical parameters is of vital importance for obtaining a maximum growth of MTB. The bacterial growth was checked at different temperature after every $24 \mathrm{~h}$. The strain TP6-4 showed high growth at $37{ }^{\circ} \mathrm{C}$ while the growth is low at 17 and $27^{\circ} \mathrm{C}$. The other bacterial strain CT-K1 also showed the same growth pattern, maximum growth at $27^{\circ} \mathrm{C}$ (Fig. 3). The growth of Strain TP6-4 was better than the growth of CT-K1 to produce magnetosomes. The bacterial growth was checked at different $\mathrm{pH}$ after every $24 \mathrm{~h}$. Both the bacterial strains showed maximum growth at 7 $\mathrm{pH}$ (Fig. 3). The graphical explanation of optimization of temperature and $\mathrm{pH}$ were shown in Figure 3.

\section{Magnetosomes extraction}

The bacterial strains TP6-4 and CT-K1 were extracted with boiling technique. The extracted product was brown in colour showed the property of iron. The extracted form of magnetosomes was showed in Figure 4. The brown coloured pallet were magnetosomes and these extracted magnetosomes were then characterized by different techniques. 


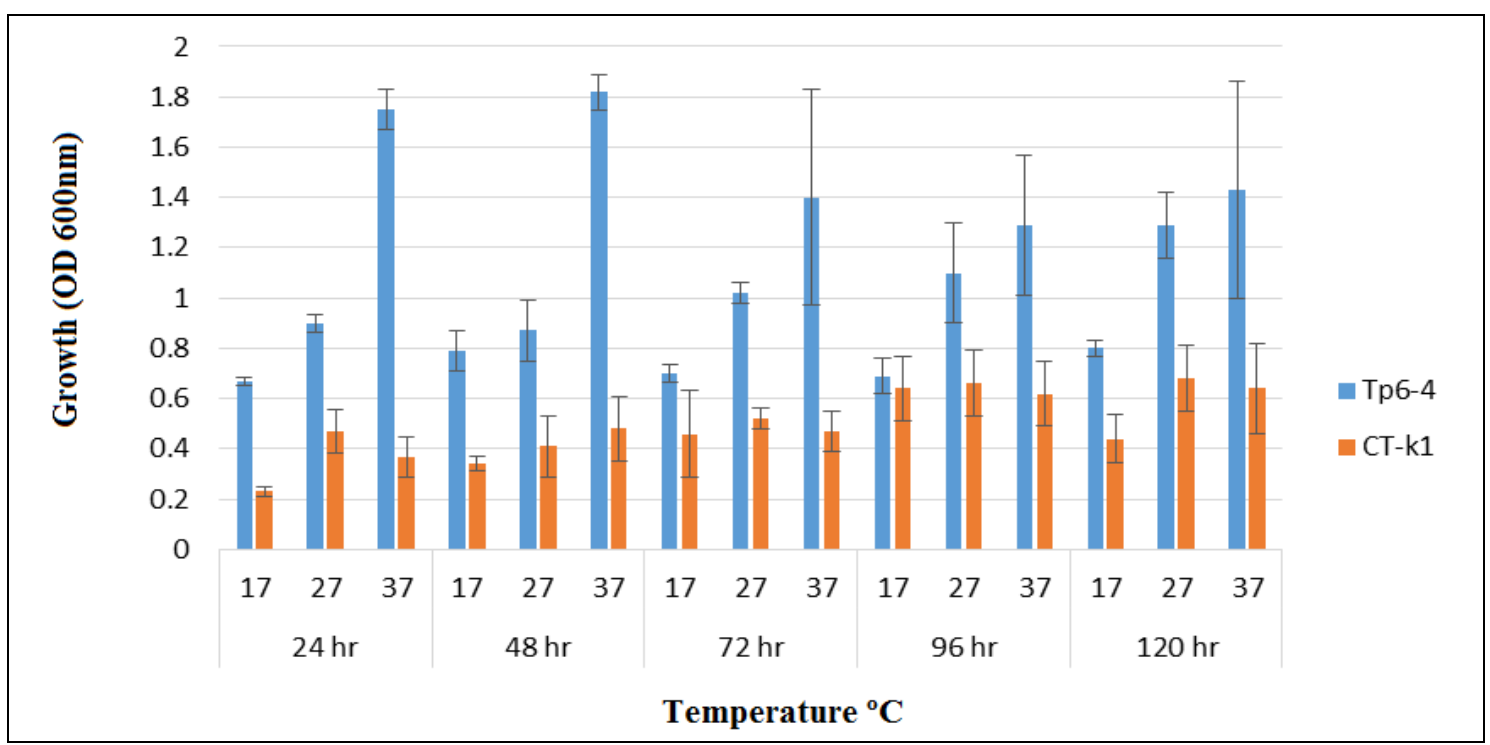

$\mathbf{a}$

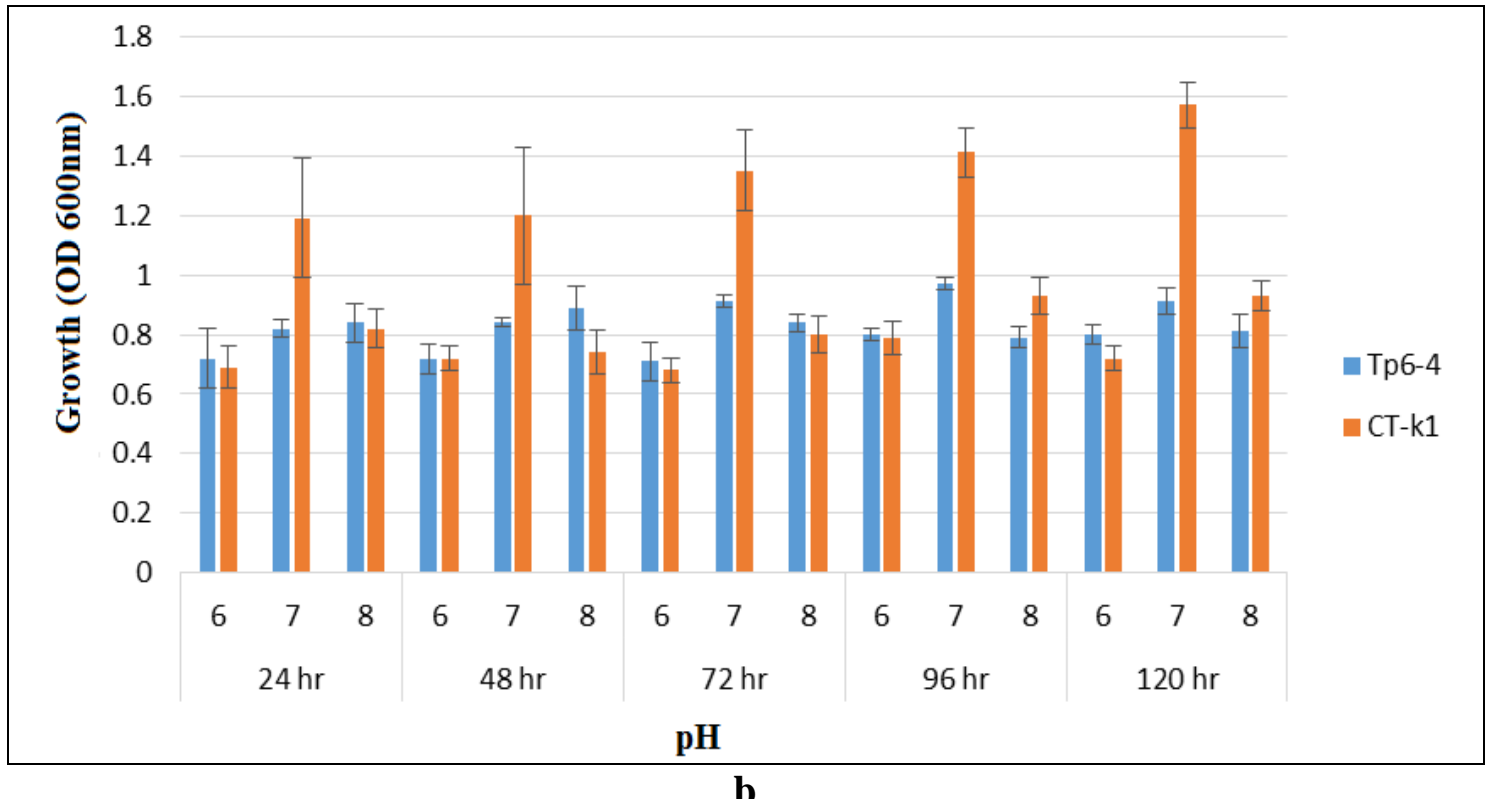

Figure 3. Effect of (a) temperature and $(b)$ pH on the growth of strains TP6-4 and CT-K1 $(p<0.05$, error bars represented the standard error)

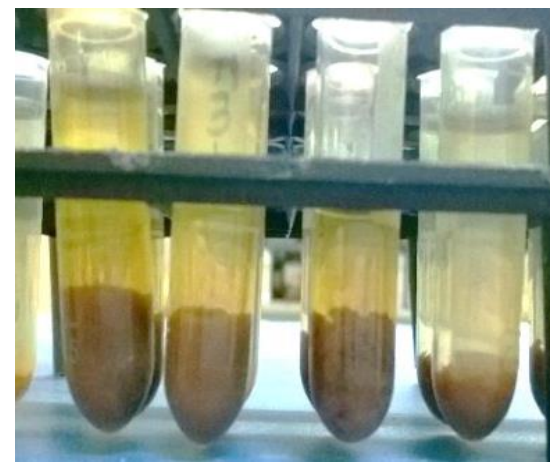

Figure 4. Collections of magnetosomes pellet after extraction 


\section{Characterization of magnetosomes}

\section{Scanning electron microscopy (SEM)}

The scanning electron Microscopy showed the structure of magnetosomes that were cleared in the figures (Fig. 5). The bacterial strain TP6-4 showed cuboidal shape of magnetosomes and CT-K1 showed hexahedral shape of magnetosomes. The sizes of the magnetosomes extracted by TP6-4 and CT-K1 were $100 \mathrm{~nm}$ and $120 \mathrm{~nm}$ respectively.
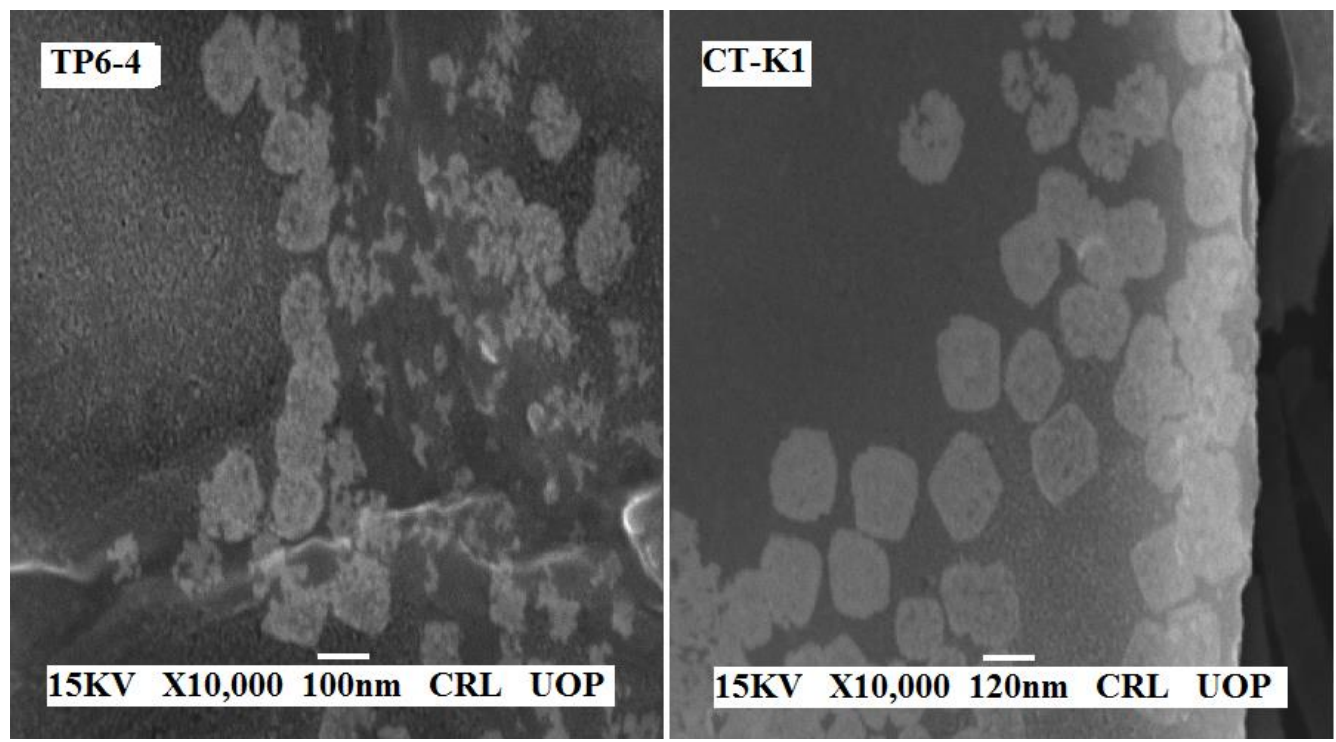

Figure 5. Scanning electron micrographs of biologically produced magnetosomes from CT-K1 and TP6-4

\section{Fourier-transform infrared spectroscopy (FTIR)}

The magnetosomes extracted from the bacteria were dried out and FTIR analysis done for the samples. The peaks at 631 and $629 \mathrm{~cm}^{-1}$ showed the Fe-O presence in the samples. The peaks appeared at 3460, 3422, 2957, 2916, 1725, 1646, 1650, 1469 and 1468 represented the $\mathrm{NH}$ bending, $\mathrm{CH}$ stretching, $\mathrm{C}=\mathrm{O}$ and $\mathrm{C}=\mathrm{C}$ stretching modes (Fig. 6).

\section{$X$-ray powder diffraction (XRD)}

The diffraction pattern in Figure 7 showed all the diffraction index of magnetite, the strong peaks at 101 at 19 and 311 at 25 representing the magnetite $\left(\mathrm{Fe}_{2} \mathrm{O}_{3}\right)$ presence in the sample. The presence of intense and broad peaks confirmed the crystalline structure present in the samples.

\section{Discussion}

Magnetotactic bacteria are a diverse group of bacteria and are found in a complex environment of oxic-anoxic transition zone of water sediment. Therefore, the isolation of these bacteria is a difficult process and required more attention for their cultivation. These bacteria accumulate the magnetite and greigite depending upon the type of environment they are present. The medium used for the cultivation of these bacteria is 
specific iron containing growth medium. This medium contained tryptone and peptone that is carbon source, ferric quinate solution that is used as an iron source for the bacterial uptake for the production of magnetosomes, $\mathrm{NaCl}$ for ion source and beef extract or meat extract for the nitrogen source (Calugay et al., 2004). Bacteria responded to the extreme intricacy of $\mathrm{Fe}^{3+}$ by discharging high similarity $\mathrm{Fe}^{3+}$ specific legends named as siderophore (Andrews et al., 2003). The molecular biology and microscopy of MTB cells discovered many new species that referred the significant phylogenetic diversity of MTB (Li et al., 2017).

The selected strains of MTB were motile and have flagella for the movement towards magnetic field lines. These bacteria may be monotrichous, peritrichous and amphitrichous according to the type of genus (Bazylinski et al., 1995; Bazylinski and Blakemore, 1983). Both the bacterial strains CT-K1 and TP6-4 are monotrichous in nature. A chemically defined medium known as sulphide indole medium was used to check the motility of the bacterial strains.
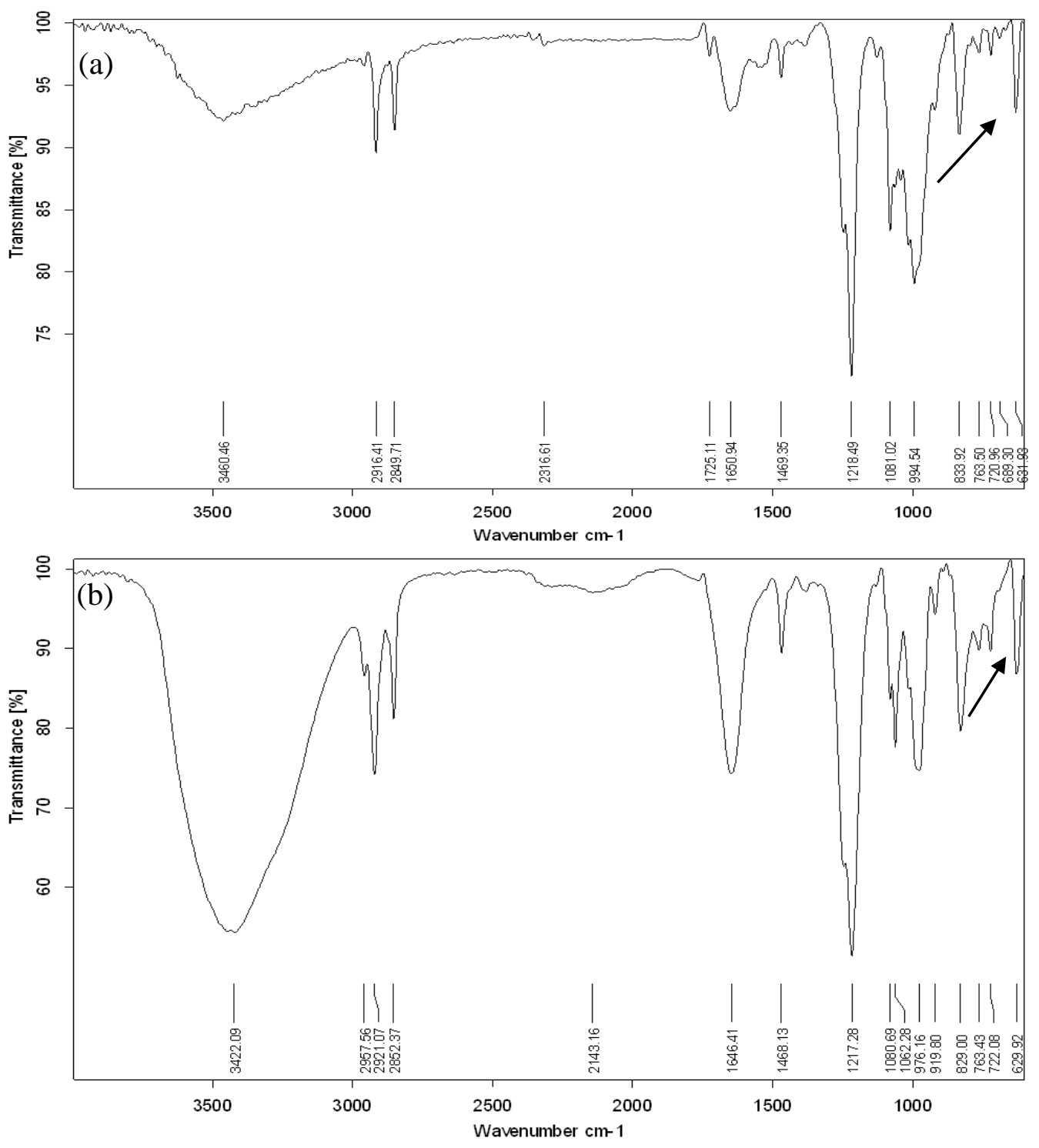

Figure 6. Fourier transform infrared spectrum of magnetosomes produced in iron specific medium extracted from (a) CT-K1 and (b) TP6-4 

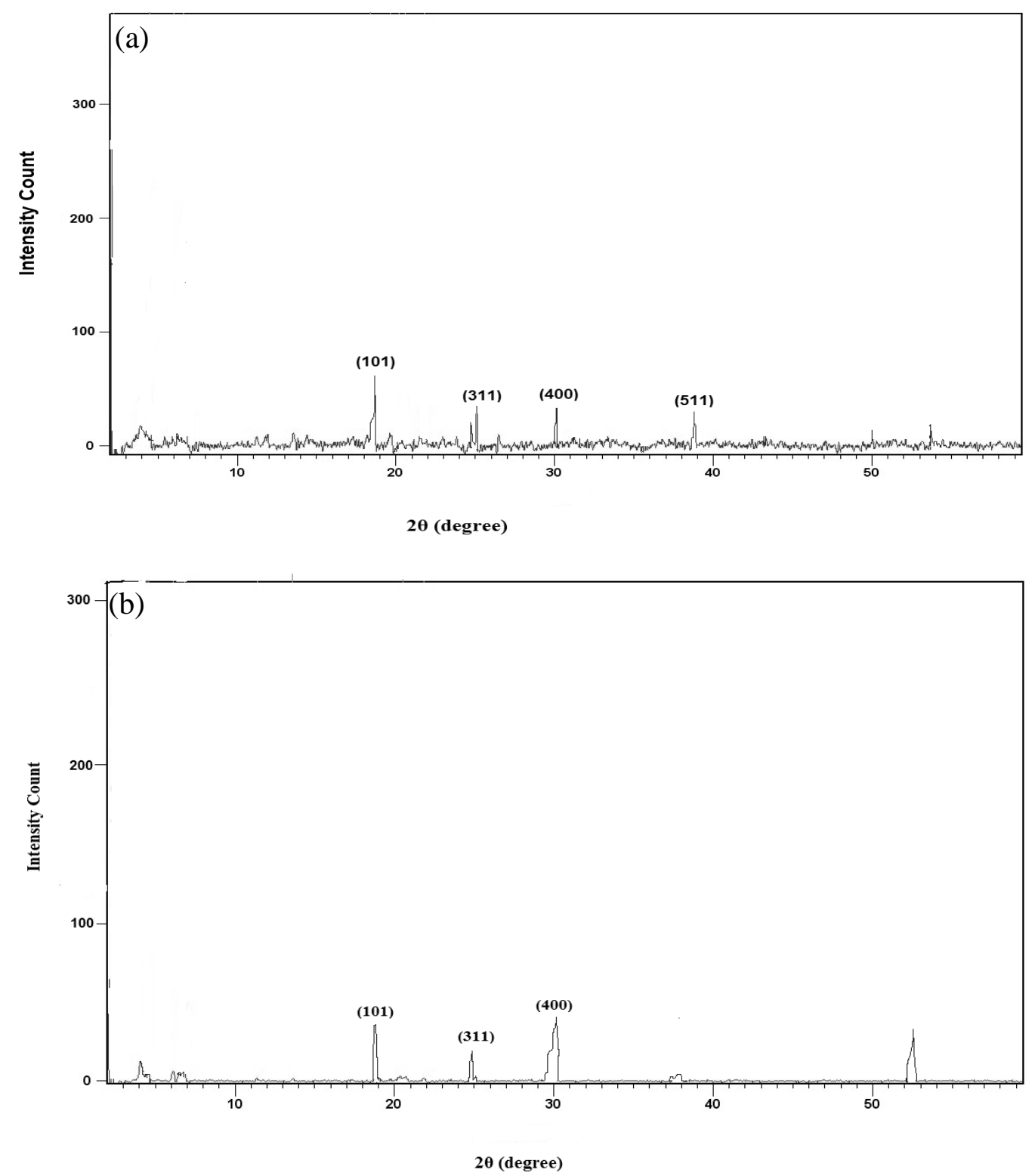

Figure 7. X-ray powder diffraction patterns of extracted magnetosomes from (a) CT-K1 and (b) TP6-4

Magnetotactic bacteria that contained chains of magnetosomes may be differentiate or identified from non-magnetotactic bacteria by magnetic assessment technique. In current study different assessment techniques were used for the isolation of bacteria containing magnetosomes. In the first technique the specific growth medium was prepared with $1 \%$ nutrient agar and strains were inoculated on medium with a magnet place aside. After 4-5 days the movement of bacteria was clearly observed towards the magnet. This was the indication that these bacterial strains contained iron particles inside their cell. In another method the inoculation of the strains was carried out on semi solid medium. These bacterial strains showed movement towards the magnet. According to Comensoli et al. (2017), the change of colour of the medium was due to the precipitation of iron oxide and iron sulphate in the medium. The change in the colour also occur due to sulphur reduction in the medium. In this study the bacteria that 
showed a clear movement towards the magnet were inoculated in the broth medium. After 10 days the colour of the medium changed to dark brown colour that indicated the bacteria consumed the iron present in the medium and produced magnetosomes. Most cultivated and uncultivated magnetotactic bacteria are related with alpha, gemma, deltaproteobacteria classes of Proteobacteria phylum and Nitrospira phylum. Freshwater MTB biomineralize magnetite $\left(\mathrm{Fe}_{3} \mathrm{O}_{4}\right)$ and $\mathrm{MTB}$ reside in marine settings, can biomineralize greigite $\left(\mathrm{Fe}_{3} \mathrm{~S}_{4}\right)$ have found in marine water (Frankel et al., 1979).

The DNA of the strains CT-K1 and TP6-4 were extracted through phenol-chloroform method (McOrist et al., 2002). The DNA was suspended in TE buffer for further process. The bacterial strain CT-K1 showed $87 \%$ resemblance with the Iron sulfide magnetotactic bacteria and the TP6-4 showed 100\% resemblance with Bacillus cereus. Both the strains were examined to produce magnetosomes. In MTB, the magnetosome biomineralization process is under genetic and biochemical control. Specific genes are involved in the biomineralization and production of the magnetosome crystals (Werckmann et al., 2017).

The MTB bacterial strains have a wide range of temperatures for their growth. Most of the reported magnetotactic bacteria have an optimum growth temperature range from 25-37 ${ }^{\circ} \mathrm{C}$ (Schuler et al., 1999). The temperature optimization was done on 17, 27 and $37^{\circ} \mathrm{C}$ for CT-K1 and TP6-4. The TP6-4 strain grew well at $37{ }^{\circ} \mathrm{C}$ while the strain CT$\mathrm{K} 1$ grew well at $27{ }^{\circ} \mathrm{C}$. The bacterial cultures showed a mesophilic nature of habitat growing best at mesophilic temperature. The basic purpose of the optimization study of parameters was to produce and extract the magnetosomes and characterized them by using analytical techniques.

In the current study, the scanning electron microscopy showed magnetosomes produced by TP6-4 were cuboidal in shape while magnetosomes produced by CT-K1 were hexahedral in shape and the size of magnetosomes were $100 \mathrm{~nm}$ (CT-K1) and $120 \mathrm{~nm}$ (TP6-4). According to the Devouard et al. (1998), the size range of the magnetosomes lied between 30 to $120 \mathrm{~nm}$. According to Keutner et al. (2014), the SEM image of single magnetosomes chain in magnetotactic bacterial cell and also individual magnetosomes. They did the SEM analysis on four magnetotactic bacterial strains of $M S-1$ on gold grid. The cryo-SEM and TEM was used to see the individual magnetosomes in bacterial cell and several rosette-like magnetosome bundles in Candidatus Magnetobacterium bavaricum from the deep branching Nitrospira phylum (Jogler et al., 2011). According to Revathy et al. (2017), the SEM and HRTEM micrograph clearly showed the cubo-octahedral shape of the magnetosome present in magnetotactic bacterial strain Magnetospirillum gryphiswaldense (MSR1).

The Fortier Transform Infrared Spectroscopy is a significant tool for the identification of function groups in a compound. The exclusive assortment of absorption bands to confirm the identity of pure compounds or detection of existence of debris. The FTIR analysis was performed for the identification of presence of iron oxide in the extracted compound. According to the FTIR analysis of iron oxide the wavelength for this is between the range of $400-650 \mathrm{~cm}^{-1}$ (Revathy et al., 2017). The wavelength for the detection of iron oxide in the analysis was at 629 and $631 \mathrm{~cm}^{-1}$ for CT-K1 and TP6-4 respectively. FTIR spectra of iron oxide was well recognized. It was being observed that the immersion band at high wavelength region was due to the $\mathrm{OH}$ enlarging and the minor wavelength because of Fe-O matrix trembling. According to the Revathy et al., the FTIR spectrum showed two peaks, in 418 and $522 \mathrm{~cm}^{-1}$ that are due to the stretching vibration mode associated with the metal and oxygen absorption band that is $\mathrm{Fe}-\mathrm{O}$ 
bonds in the crystalline lattice of $\mathrm{Fe}_{3} \mathrm{O}_{4}$. According to Xiang et al. in (2007), the FTIR analysis of purified magnetosomes showed peaks at 3273, 2921, 1735, 1531 and $1645 \mathrm{~cm}^{-1}$. The peaks appeared at 3273 and $2921 \mathrm{~cm}^{-1}$ were representing the $\mathrm{NH}$ bending and $\mathrm{CH}$ stretching modes. These carbon and nitrogen bonding were representing the lipid bilayer and protein in the magnetosomes membrane. $\mathrm{C}=\mathrm{O}$ and $\mathrm{C}$ $=\mathrm{C}$ stretching modes peaks were appeared at 1735,1645 and $1531 \mathrm{~cm}^{-1}$. FTIR analysis can also be used for the purity examination of magnetosomes. In the current study, the peaks appeared at 3460 and $2916 \mathrm{~cm}^{-1}$ in the sample of CT-K1 and peaks appeared at 3422 and $2957 \mathrm{~cm}^{-1}$ in the sample of TP6-4. The $\mathrm{C}=\mathrm{O}$ and $\mathrm{C}=\mathrm{C}$ stretching modes peaks were appeared at 1725 and $1650 \mathrm{~cm}^{-1}$ in the sample of CT-K1 and peaks appeared at 1646 and $1468 \mathrm{~cm}^{-1}$ in the sample of TP6-4. This study showed significant results for the characterization of magnetosomes.

The X-rays diffraction analysis showed presence of inverse spinel structure of iron oxide. The $2 \theta$ corresponded to the scattering angle of the crystal, the more the sharp edge of the sample the clearer will be the peak. The peaks of 101 and 311 showed the presence of iron oxide in sample and the broad spectrum is due to the crystallinity of the iron oxide. According to Bini et al. (2012), the peaks at wavelength 311 showed the iron oxide crystallinity. While according to Revathy et al. (2017) Magnetospirillum gryphiswaldense (MSR-1) produced magnetosomes and the peaks appeared at 27.05, $30.30,35.71,43.31,55$, corresponds to the $\mathrm{Fe}_{3} \mathrm{O}_{4}$. In the current study, the peaks showed resemblance to the 27 (311), 30 (400) and 38.5 (511). These results revealed that the XRD analysis showed the presence of $\mathrm{Fe}_{3} \mathrm{O}_{4}$ in sample. These results of characterization of magnetosomes produced from Iron sulfide magnetotactic bacteria were given good evidences to use then in future studies.

\section{Conclusion}

Conclusively, the current study helped in finding the newest class of bacteria from the fresh water samples of Pakistan. This has been the tremendous and improved development in the field of microbiology to isolate the class of magnetite producing bacteria. This current study extensively investigated the new ways to isolate these magnetosomes producing bacteria from fresh water bodies. The diversity and ecology of intracellular bio-mineralizing bacteria and their molecular mechanisms of intracellular biomineralization are needed to be studied. The optimised bacterial strain helped in the maximum production of magnetosomes that would be used in many applications. The extracted magnetosomes shape was characterised by scanning electron microscopy so that significant potential use of magnetosomes in different application and ensuring high yield, increased reliability and stability in optimized conditions.

\section{REFERENCES}

[1] Andrews, S. C., Robinson, A. K., Rodriguez-Quinones, F. (2003): Bacterial iron homeostasis. - FEMS Microbiol Rev 27: 215-237.

[2] Arakaki, A., Nakazawa, H., Nemoto, M., Mori, T., Matsunaga, T. (2008): Formation of magnetite by bacteria and its application. - J Roy Soc Interface 5: 977-99.

[3] Bazylinski, D. A., Blakemore, R. P. (1983): Denitrification and assimilatory nitrate reduction in Aquaspirillum magnetotacticum. - Appl Environ Microbiol 46: 1118-1124. 
[4] Bazylinski, D. A., Frankel, R. B. (2004): Magnetosome formation in prokaryotes. - Nat Rev Microbial 2: 217-230.

[5] Bazylinski, D. A., Frankel, R. B., Heywood, B. R., Mann, S., King, J. W., Donaghay, P. L., Hanson, A. K. (1995): Controlled biomineralization of magnetite (Fe(inf3)O(inf4)) and greigite $(\mathrm{Fe}(\mathrm{inf} 3) \mathrm{S}(\mathrm{inf} 4))$ in a magnetotactic bacterium. - Appl Environ Microbiol 61(9): 3232-3239.

[6] Bazylinski, D. A., Dean, A. J., Schüler, D., Phillips, E. J., Lovley, D. R. (2000): $\mathrm{N}_{2^{-}}$ dependent growth and nitrogenase activity in the metal-metabolizing bacteria, Geobacter and Magnetospirillum species. - Environ Microbiol 2: 266-273.

[7] Bini, R. A., Marques, R. F. C., Santos, J. F., Chaker, A. J., Jafelicci, J. M. (2012): Synthesis and functionalization of magnetite nanoparticles with different aminofunctional alkoxysilanes. - J Magnetism Magnetic Mater 324: 534-539.

[8] Calugay, R. J., Okamura, Y., Wahyudi, A. T., Takeyama, H., Matsunaga, T. (2004): Siderophore production of a periplasmic transport binding protein kinase gene defective mutant of Magnetospirillum magneticum AMB-1. - Biochem Biophys Res Commun 323(3): 852-867.

[9] Comensoli, L., Maillard, J., Albini, M., Sandoz, F., Junier, P., Joseph, E. (2017): Use of bacteria to stabilize archaeological iron. - Appl Environ Microbiol 17: 83(9).

[10] Devouard, B., Posfai, M., Hua, X., Bazylinski, D. A., Frankel, R. B., Buseck, P. R. (1998): Magnetite from magnetotactic bacteria; size distributions and twinning. - Am Mineral 83: 1387-1398.

[11] Flies, C. B., Peplies, J., Schüler, D. (2005a): Combined approach for characterization of uncultivated magnetotactic bacteria from various aquatic environments. - Appl Environ Microbiol 71: 2723-2731.

[12] Flies, C. B., Jonkers, H. M., de Beer, D., Bosselmann, K., Böttcher, M. E., Schüler, D. (2005b): Diversity and vertical distribution of magnetotactic bacteria along chemical gradients in freshwater microcosms. - FEMS Microbiol Ecol 52: 185-195.

[13] Frankel, R. B., Blakemore, R. P., Wolfe, R. S. (1979): Magnetite in freshwater magnetotactic bacteria. - Science 203: 1355-1356.

[14] Jogler, C., Wannera, G., Kolinkoa, S., Nieblera, M., Amannb, R., Petersena, N., Kubec, M., Reinhard, R., Schülera, D. (2011): Conservation of proteobacterial magnetosome genes and structures in an uncultivated member of the deep-branching Nitrospira phylum. - PNAS 108(3): 1134-1139.

[15] Jogler, C., Niebler, M., Lin, W., Kube, M., Wanner, G., Kolinko, S. (2010): Cultivationindependent characterization of 'Candidatus Magnetobacterium bavaricum' via ultrastructural, geochemical, ecological and metagenomic methods. - Environ Microbiol 12: $2466-2478$.

[16] Keutner, C., Bohlen, A., Berges, U., Espeter, P., Schneider, C. M., Westphal, C. (2014): Photoemission electron microscopy and scanning electron microscopy of Magnetospirillum magnetotacticum's magnetosome chains. - Anal Chem 86: 9590-9594.

[17] Kirschvink, J. L., Walker, M. M., Diebel, C. E. (2001): Magnetite-based magnetoreception. - Curr Opin Neurobiol 11: 462-467.

[18] Lefevre, C. T., Bazylinski, D. A. (2013): Ecology, diversity, and evolution of magnetotactic bacteria. - Microbiol Mol Biol Rev 77(3): 497-526.

[19] Lefèvre, C., Frankel, R., Pósfai, M., Prozorov, T., Bazylinski, D. A. (2011): Isolation of obligately alkaliphilic magnetotactic bacteria from extremely alkaline environments. Environ Microbiol 13(8): 2342-50.

[20] Li, J., Zhang, H., Menguy, N., Benzerara, K., Wang, F., Lin, X., Chen, Z., Pan, Y. (2017): Single-cell resolution study of uncultured magnetotactic bacteria via fluorescence-coupled electron microscopy. - Appl Environ Microbiol 83(12).

[21] Lin, W., Zhang, W., Zhao, X., Roberts, A. P., Paterson, G. A., Bazylinski, D. A., Pan, Y. (2018): Genomic expansion of magnetotactic bacteria reveals an early common origin of magnetotaxis with lineage-specific evolution. - ISME J 12(6): 1508-1519. 
[22] Loghin, D., Tremblay, C., Mohammadi, M., Martel, S. (2017): Exploiting the responses of magnetotactic bacteria robotic agents to enhance displacement control and swarm formation for drug delivery platforms. - Int J Robotics Res 36(11): 1195-1210.

[23] Revathy, T., Jayasri, M. A, Suthindhiran, K. (2017): Toxicity assessment of magnetosomes in different models. - 3 Biotech 7: 126.

[24] Schuler, D., Spring, S., Bazylinski, D. A. (1999): Improved technique for the isolation of magnetotactic spirilla from freshwater sediment and their phylogenetic characterization. Syst Appl Microbiol 22: 466-471.

[25] Sharma, G. P., Chandrajit, B. (2011): Preliminary isolation report of aerobic magnetotactic bacteria in a modified nutrient medium. - Recent Res Sci Technol 3(11): 71-75.

[26] Shivangi, U., Sinha, A. (2011): Magnetotactic bacteria and their application in environmental clean-up: A review. - Int. Res. J. Environment Sci 6(7): 63-68.

[27] Simmons, S. L., Sievert, S. M., Frankel, R. B., Bazylinski, D. A., Edwards, K. J. (2004): Spatiotemporal distribution of marine magnetotactic bacteria in a seasonally stratified coastal salt pond. - Appl Environ Microbiol 70: 6230-6239.

[28] Tanaka, M., Arakaki, A., Staniland, S. S., Matsunaga, T. (2010): Simultaneously discrete biomineralization of magnetite and tellurium nanocrystals in magnetotactic bacteria. Applied and Environmental Microbiology 76(16): 5526-5532.

[29] Waghmare, V., Kale, S., Pawar, K., Metri, A. (2018): Isolation, identification of magnetotactic bacteria and their magnetosomes from lonar lake. - Int J Current Res Life Sci 7(4): 1858-1862.

[30] Werckmann, J., Cypriano, J., Lefèvre, C. T., Dembelé, K., Ersen, O., Bazylinski, D. A., Lins, U., Farina, M. (2017): Localized iron accumulation precedes nucleation and growth of magnetite crystals in magnetotactic bacteria. - Scientific Reports 7(1): 8291.

[31] Xiang, L., Wei, J., Jianbo, S., Guili, W., Feng, G., Ying, L. (2007): Purified and sterilized magnetosomes from Magnetospirillum gryphiswaldense MSR-1 were not toxic to mouse fibroblasts in vitro. - Letters Appl Microbiol 45: 75-81. 